\title{
mi:IESE SP-SP
}

University of Navarra

\section{Working Paper}

WP No 504

April, 2003

THE INTEGRATION OF EU BANKING MARKETS

Jordi Gual *

* Professor of Economics, IESE 
The Public-Private Center (SP-SP) is a Research Center based at IESE Business School. Its mission is to develop research that analyses the relationships between the private and public sectors primarily in two areas: regulatory (the effects of regulation on private economic activity) and contractual (the total or partial transfer of public services to the private sector). Research results are disseminated through publications, conferences and colloquia. These activities are aimed to foster cooperation between the private sector and public administrations, as well as the exchange of ideas and initiatives.

The sponsors of the SP-SP Center are the following:

- Accenture

- Ajuntament de Barcelona

- Official Chamber of Commerce, Industry and Navigation of Barcelona

- BBVA

- Diputació de Barcelona

- Garrigues, Abogados y Asesores Tributarios

- Catalan Government (Generalitat de Catalunya)

- Grupo MSD

- Patronat Català Pro-Europa

- Swiss Life (España)

- Telefónica, S.A.

- T-Systems.

The content of this publication reflects the conclusions and findings of the individual 
authors, and not the opinions of the Center's sponsors.

\title{
THE INTEGRATION OF EU BANKING MARKETS
}

\begin{abstract}
The goal of this paper is to provide an assessment of the EU policies that pursue the creation of a single banking market. The paper evaluates the degree of integration of EU banking markets and discusses whether current policies are the most appropriate instruments for market integration. After comparing the key features of EU policy with alternative methods of market opening, the analysis stresses that market opening in regulated markets such as banking faces a difficult trade-off between respect for domestic preferences and the elimination of regulations that protect local competitors and are not justified on efficiency grounds. The paper also provides an overview of recent research which has looked at different indicators of market integration in EU banking. Finally, it analyzes the impact of integration policies on the conduct, the structure and the performance of the banking industry.
\end{abstract}

Keywords: Integration policies, banking industry, European Union, market integration, regulated markets, market structure, single market 


\section{THE INTEGRATION OF EU BANKING MARKETS}

\section{Introduction ${ }^{1}$}

The goal of this paper is to provide an assessment of the EU policies that pursue the creation of a single banking market. The paper evaluates the degree of integration of EU banking markets, the impact of the integration process on the conduct, the structure and the performance of the industry at the EU level, and discusses whether current policies are the most appropriate instruments for market integration.

After this introduction, the second section of the paper summarizes the key features of EU policy and compares this policy with alternative methods of market opening. The analysis stresses that market opening in regulated markets such as banking faces a difficult trade-off between respect for domestic preferences and the elimination of regulations that protect local competitors and are not justified on efficiency grounds.

The third section provides an overview of recent research which has looked at different indicators of market integration in EU banking and analyzes the data on crossborder establishments and national and EU-wide concentration as key indicators of progress in European integration. In this respect, the US banking industry provides an interesting benchmark, which is used whenever comparable information is available.

The fourth section analyzes the impact of integration policies on the conduct, the structure and the performance of the banking industry. The objective is to assess whether EU integration has contributed to increasing the efficiency of the EU banking industry through cost reductions and lower markups. The study of changes in the degree of rivalry focuses on the behaviour and the determinants of the pass-through from interbank rates to retail rates. These changes are considered together with the data on the restructuring of the industry through mergers and acquisitions and the evolution of efficiency and profitability measures.

A final section provides an integrative assessment, summarizing the key results of the paper and evaluating the extent to which the changes in the degree of integration and the performance of the industry imply that the EU single market policies have achieved their objectives.

1 Comments by Bruno Cassiman are gratefully acknowledged. 


\section{The integration policy of the EU in banking}

The EU has been implementing banking directives for many years, with the goal of achieving a single EU banking market. This program is part of a broader mandate to create a single market for services. In banking, a single market means that any provider of banking services can establish itself (or acquire banks) across the Union, and that customers can bank with any credit institution legally established in the Union. These are the well-known free trade and freedom of establishment principles. In the case of banking, the second principle includes not only the setting up of subsidiaries that receive no different treatment from domestic banks but also foreign branches that need not be locally incorporated.

The problem is, of course, that achieving the goals of free trade and cross-border investment in banking is especially complex due to the fact that the industry is heavily regulated.

For the purpose of analyzing the integration process, we are going to distinguish three types of regulation ${ }^{2}$. The first includes prudential regulation. That is, all those restrictions on banks which are introduced with the objective of mitigating the market failures that arise in the banking business (for example, negative externalities that provoke bank runs, or asymmetric information problems that lead to excessive risk taking). These regulations include solvency and own funds requirements, limits on large exposures and rules regarding participation in non-financial firms or activities. Deposit guarantee schemes which attempt to thwart the appearance of bank runs are also included under this heading. In general, all these restrictions impose a (private) cost on banks, but in principle they are justified as interventions with the goal of correcting a situation of market failure.

The second type of regulation comprises restrictions imposed directly on the structure of the industry and the conduct of business. The conventional list of these regulations is very long, including direct restrictions on entry, limits on the number of competitors or the number of branches and the geographical scope of banks, direct rate regulation and rules on lines of business that banks can undertake or specific financial products that they can market. The justification of these measures has not been in general directly linked to a concern for market failures. They have been, however, pervasive in many countries. It is true that very often these measures soften competition and increase the franchise value of the banks, thus limiting the incentives for banks to engage in excessive risk taking. But the increase in market power is not necessarily the most efficient way to handle the moral hazard problem, and the economic regulations that limit entry do not deal directly with an externality problem and may easily be the result of pressure exerted by incumbent firms on the regulator. Similarly, regulations which limit the scope of banking activities or the freedom to determine prices can certainly reduce the riskiness of credit institutions, but they are not necessarily the most appropriate instruments for this regulatory objective.

A third type of regulation concerns the information that is required from credit institutions regarding both the characteristics of banking products and services, and the soundness of their financial situation. This regulation attempts to reduce the serious informational asymmetries which arise in the banking relationship. A depositor has little knowledge of the quality of the banking assets that he holds indirectly, and this may inefficiently limit the expansion of banking activities unless some control is imposed on the

\footnotetext{
2 See White (1996).
} 
information provided by banks.

Regulatory restrictions lead to two sorts of problems that may undermine or call into question the integration process. First, some banking services may be subject to different regulatory treatment across the Member States. For example, checking accounts may or may not be allowed to provide interest. This difference in regulations could prevent the deployment of EU-wide product strategies and limit some of the scale advantages that the single market could provide. Second, credit institutions may be subject to a different set of regulatory restrictions. In certain countries, for example, banks may undertake insurance and investment banking activities while in other markets this is forbidden. This conflict was present, for example, in the trade agreements between Canada and the US before the derogation of the Glass-Steagall Act. The Act did not allow US credit institutions to undertake activities similar to those permitted to Canadian banks. In both cases, the conflicting regulatory situations lead to instances of asymmetric regulatory treatment across the Union that may distort business decisions both in terms of cross-border trade and establishment.

As a result of the complex layers of regulation which affect the industry, the integration process implies not only that barriers to trade and investment are eliminated, but also that some decisions have to be taken with regard to how a service consumed abroad is regulated, and how a firm is regulated when it operates abroad. At least three solutions are possible.

The first consists of the full harmonization of regulatory restrictions. Such a solution eliminates, of course, the problems of regulatory asymmetry, and it certainly paves the way for a fully integrated banking market. However, it is a solution which is very soon discarded as unfeasible in the absence of full political integration. This is so, because the regulation of financial products is very much linked to commercial and contract law, and this is an area where traditions differ substantially across countries.

A second alternative is the use of the national treatment principle ${ }^{3}$. This principle states that foreign providers have to be allowed access to the local market and must be treated in all respects no differently from domestic providers. This principle allows each country to maintain different regulations, provided that there is no discrimination among providers on the grounds of country of origin. The national treatment principle is one of the cornerstones of the trade liberalization agreements for goods (GATT), but was not adopted as a basic principle in the trade agreement which covers financial services (GATS). In this agreement, granting national treatment as well as providing access are subject to negotiations. Countries joining the agreement commit only to the most favoured nation principle -and even then with some exemptions- and to the principles of transparency and the availability of national remedies 4 .

The national treatment principle is straightforward with regard to foreign establishments, since it implies that foreign providers are subject to the local rules. It is, however, more controversial when referring to cross-border trade, as exemplified by the provisions in the North American Free Trade Agreement. This agreement goes beyond the terms of the GATS and incorporates explicitly the national treatment principle (Art. 1405). It applies both to subsidiaries (establishments) and cross-border providers. However,

3 See, for example, Van Empel and Mörner (2000).

4 The most favoured nation principle implies that any trade advantage that is conferred to one specific trade partner has to be extended to the rest. Measures dealing with prudential goals are not affected by the trade agreements. 
the agreement allows any of the parties to require the registration of cross-border financial services providers of another party, and of financial instruments (Art.1404.3), and does not oblige any of the parties to allow cross-border selling of those services (the obligation of access under the national treatment principle "does not require a Party to permit such providers to do business or solicit in its territory (...) each Party may define 'doing business' and 'solicitation' for purposes of this obligation").

Overall, the national treatment principle allows market access (establishment) and a substantial degree of free trade, but it is clearly insufficient if the objective is the creation of a single market. It leads to the maintenance of several regulatory regimes that the credit institution has to comply with if it wants to operate across all the free trade area and, as shown in the case of NAFTA, it is difficult to apply in the case of cross-border services

The third integration method is based on the mutual recognition principle. Mutual recognition implies that each country acknowledges the regulation of its partners and accepts service-provision by foreign institutions as if they were domestic entities. Mutual recognition allows the maintenance of different rules in the participating countries, but the granting of market access without establishing a harmonized regulation implies that institutions from different countries will compete subject to different regulatory constraints. Since these constraints will usually undermine the competitive position of banks, regulatory institutions are likely to engage in a process of competitive deregulation, attempting to ensure that the entities under their regulatory control are not handicapped relative to their competitors. Moreover, banks are likely to alter their strategies -including their location- to take advantage of the more favourable regulatory environment. It appears, therefore, that mutual recognition could foster a high degree of market integration, but also undermine the effectiveness of regulations and lead to what sometimes is described as a regulatory meltdown.

When attempting to integrate regulated industries such as banking, which of the three systems that we have reviewed is most appropriate? One way to answer this question is to assess what are the implications of each system for the three types of regulation that we have distinguished above. Does the chosen integration method provide sufficient guarantees that sound regulatory tools remain in place?

The full harmonization process guarantees market integration and may also ensure compliance with prudential regulatory goals if the right instruments are put in place. Similarly, it can provide for the elimination of harmful economic regulation. However, to the extent that the harmonization affects information and consumer protection regulation, it can lead to a loss of diversity which should be taken into account as a negative impact.

The national treatment method provides a limited degree of integration but guarantees that national regulatory goals are maintained, for both prudential and information regulation. Economic regulation may be undermined by the integration process, since allowing market access on a non-discriminatory basis implies that domestic firms may face, in the domestic marketplace, foreign competitors which are regulated differently (and to their advantage) in their home country. Since economic regulation is not seriously grounded on any well-defined market failure problem, deregulation triggered by market access may indeed be a welcome process which erodes harmful market interventions.

Mutual recognition, finally, results also in a high degree of integration, but will lead to the disappearance of those regulations which either increase the cost of domestic institutions or divert banking activities abroad. This includes prudential rules fundamentally, 
and to a lesser degree information regulation and economic regulation. The process of market integration in the European Union has been based on the method of mutual recognition, although with some adjustments which attempt to limit the process of regulatory competition. Mutual recognition has been complemented with the establishment of harmonized standards with regard to prudential regulations. This is appropriate. It is clear that these regulations are targeting a well-defined and sound social objective. Since they impose costs on banks, reducing their international competitiveness, they could easily lead to regulatory arbitrage. Note also that the harmonizing regulation established a minimum standard and did not prevent individual countries from enforcing even stricter prudential requirements.

The EU integration process does not set any minimum standards with regard to economic regulation; in fact, it establishes the predominance of the universal banking model, allowing credit institutions to engage in both commercial and investment banking activities. Nor does it impose regulations on the provision of other financial services (such as insurance) or on other aspects of banking conduct. This approach is based on the belief that mixed competition will foster the lifting of economic regulations which are not justified by the existence of market failure (eliminating controls on rates, allowing the expansion of banking firms geographically and across financial activities, etc.), on the understanding that the minimum prudential standards will ensure that this deregulation process does not lead to excessive risk taking and solvency problems.

As for the risk of excessive regulatory competition in the area of information regulation, the European Union has tackled the problem by introducing an exception to the mutual recognition principle. It allows the host country to regulate in this area. This amounts to using the national treatment rule for regulations that attempt to protect the consumer. In practice, this exception has been implemented through the introduction of the general good clause. This clause allows the domestic authorities to deny access to the domestic market to foreign providers or foreign financial services when it is deemed that the general interest is at risk.

Overall, the process of mutual recognition coupled with the harmonization of prudential regulation and the rules on host country control for consumer protection issues have allowed the process of EU banking integration to proceed much faster than in the past -when full harmonization was attempted- and achieve a deeper integration than can be obtained through the use of the national treatment principle (as in the NAFTA process).

Despite this progress, several issues remain highly controversial and, according to some observers, stand in the way of full integration. First, the competitive deregulation process has not led to similar degrees of liberalization across countries, with the persistence of some asymmetric regulation situations. For example, some peculiarities persist in terms of institutions in countries such as Germany, Spain, France or Greece. A second set of problems arises from the use of the general good clause as a tool to maintain regulatory control by the host country. For example, countries such as France do not allow interest-bearing checking accounts and claim that allowing foreign banks to supply this product would harm the general interest because it would trigger an increase in the commissions paid by the less well-off customers 5 .

More generally, despite mutual recognition, the host country is still allowed, in the

5 See Sun and Pelkmans (1995). A recent case on the same issue has involved a subsidiary of a Spanish saving bank. 
name of the general good, to control key aspects of the marketing and information provided for financial products (for example, on UCITS $^{6}$ ) and these regulations are perceived by foreign banks as important restrictions that prevent the exploitation of scale economies for the whole EU.

Finally, a third group of problems refers to the different national regulation of certain products, particularly with regard to their tax treatment. This excludes the straightforward case of tax discrimination between providers of different origin 7 , which is clearly against EU law. Rather, it refers to the fact that across the EU a similar product, such as a pension fund, must satisfy very different sets of requirements to qualify for special tax treatment ${ }^{8}$.

As we have seen, the system of market integration adopted by the EU is a combination of three alternative methods: mutual recognition (with home country regulations), a limited dose of harmonization, and national treatment through the exceptions granted by the general good clause that gives the host country control over certain issues. The conceptual framework developed in this section allows us to analyze the remaining contentious issues in a systematic way.

With regard to the asymmetric (and potentially distorting) regulatory treatment of some institutions in certain countries, one way to tackle the issue is through the use of the authority of the EU in terms of general competition law. After all, this differential regulatory treatment will be a matter of concern only if the different treatment of institutions has an impact on competition, whether against domestic or foreign players.

On the question of the use of the general good clause, the analysis is more complex. Consider a country A which does not allow interest-bearing checking accounts and a country $\mathrm{B}$ that does. The general good clause may be used to prevent a firm from B from offering its service in A directly through a branch or subsidiary (although no one can prevent a customer from A from banking in B and opening an interest-bearing checking account there). Similarly, consider a country A which does not allow early loan repayments and a country B that does. Can we use the general good principle to prevent a bank from B from operating in A directly (through branches or subsidiaries)?

In both cases, $\mathrm{A}$ is the more heavily regulated country and $\mathrm{B}$ is the less regulated one, and the introduction of the general good clause stops the competitive deregulation process. Both cases arise because harmonization has taken place at the level of definition of the banking licence but not at the level of individual products. Is the exception to mutual recognition justified in these instances? Is it justified, for example, in the case of checking accounts in terms of local preferences for solvency, say, or to avoid transaction charges, if it is felt that this would hurt poor customers (equity goal). To what extent can one argue that this is just a protectionist excuse?

As for leaving the control of marketing to host authorities, this may make sense if we are to respect national preferences, even if it implies a certain loss in terms of scale economies. Ultimately, two issues should be studied in detail. First, the extent to which these

6 Undertakings for Collective Investments in Transferable Securities. See Heinemann and Jopp (2002), page 52 .

7 See Heinemann and Jopp, op. cit. page 52-53.

8 The report to the European Roundtable for Financial Services (Heinemann and Jopp, op. cit.) refers to the Riester products in Germany, which must satisfy stringent conditions to qualify for tax advantages. Similar restraints are imposed in other countries for the contributions to these funds to be tax-deductible. 
local rules may in practice act as barriers to foreign providers. And, second, the need for these local rules to assess whether home-country rules exist that offer similar protection to the protection that the domestic (host) regulators are trying to introduce.

Finally, when national regulations differ due to different tax treatments of financial products (and other social features), this makes sense to the extent that there is no harmonization of tax and social policy in the EU. Again, there might be some loss in terms of unfulfilled integration, but this may be counterbalanced by the respect of domestic preferences.

\section{Are EU banking markets integrated?}

The banking industry comprises a variety of market segments, in which the nature of competition is diverse and in which we would expect to observe different degrees of market integration. For each market segment, we can assess the extent of integration as it is usually done in trade theory. We can focus on the evolution of price convergence, or we can look at a quantity indicator, such as cross-border flows or, in the case of direct investment, the market share of foreign entities.

Price convergence implies that price differentials for the same financial service should be eliminated over time, or at least greatly reduced, down to the level justified by the existence of significant arbitrage or transportation costs.

As for quantities, it should be stressed that this is a complementary indicator. Indeed, the absence of cross-border flows (or the small market share of foreign competitors) need not be incompatible with a substantial degree of integration, provided that the threat of foreign entry/competition keeps the markets integrated -with price differences which do not exceed the costs of arbitrage.

In financial services there is, of course, an additional channel of integration. The final customers (typically, companies on the borrowing side, families on the lending side) may access foreign markets indirectly to the extent that the financial intermediaries themselves become internationalized. For example, domestic investors may buy UCITS from local credit institutions that invest in foreign equities. Similarly, companies may issue bonds which are placed in the international market by a local institution.

Let us consider next the degree to which geographic market integration has been achieved in the EU for each market segment. The most integrated markets are the money and the government bond markets. These are markets where the products are highly standardized and integration was practically achieved with the advent of the single currency, which eliminated the remaining segmentation of the markets due to currency denomination. 
Table 1. Average spreads before and after European Monetary Union*

\begin{tabular}{|c|c|c|c|c|c|c|c|c|}
\hline & \multicolumn{2}{|c|}{ Interbank 3-month rates } & \multicolumn{2}{|c|}{ Benchmark 10-year yields } & \multicolumn{2}{|c|}{ Mortgage rates } & \multicolumn{2}{|c|}{ Corporate loans rates } \\
\hline & \begin{tabular}{|l} 
Before '99 \\
\end{tabular} & After '99 & Before 99 & After '99 & \begin{tabular}{|l} 
Before '99 \\
\end{tabular} & After '99 & Before '99 & After '99 \\
\hline Austria & 10 & 0 & 15 & 25 & 47 & 0,1 & -89 & -199 \\
\hline Belgium & 7 & 0 & 32 & 31 & -8 & 35 & -332 & -343 \\
\hline Denmark & 80 & 53 & 85 & 37 & n.a. & n.a. & -167 & -246 \\
\hline Finland & 40 & 0 & 84 & 22 & 19 & -41 & -249 & -351 \\
\hline France & 74 & 0 & 21 & 13 & 183 & 73 & -142 & -308 \\
\hline Greece & 1059 & 380 & n.a. & n.a. & n.a. & 188 & 1234 & 413 \\
\hline Ireland & 216 & 0 & 85 & 14 & 87 & -49 & 202 & 87 \\
\hline Italy & 404 & 0 & 262 & 32 & 488 & 43 & 251 & -207 \\
\hline Luxembourg & n.a. & n.a. & -12 & 19 & n.a. & n.a. & n.a. & n.a. \\
\hline Netherlands & -12 & 0 & $-0,6$ & 14 & 13 & 161 & -435 & -376 \\
\hline Portugal & 316 & 0 & 204 & 33 & 376 & -3 & 245 & -248 \\
\hline Spain & 299 & 0 & 208 & 28 & 213 & -28 & -54 & -335 \\
\hline Sweden & 224 & -7 & 171 & 27 & 186 & 93 & -45 & -304 \\
\hline
\end{tabular}

* Basis points. Spreads relative to German rates. The data before 1999 refer to the period January 1995 December 1998.

The period after 1999 refers to January 1999 - September 2001.

n.a.: not available.

Source: Adam et al. (2002).

Consider, first, the interbank market. Table 1 shows how the spread between the German interest rate and the local rate has collapsed to zero for eurozone countries. It has also gone down significantly for the rest of the EU. It is worth pointing out that this practically full convergence has been achieved with an intra-EU market share of interbank claims of around 17\%, as reported by Danthine et al. for the end of $19999^{9}$. This confirms that these markets can become integrated even if the market shares of local players are fairly large. Adam et al. also demonstrate for this market that beta convergence (the reduction in the dispersion of rates) has accelerated in recent times and that, in fact, full convergence was achieved thanks to EMU.

As for the public bond market, the same sort of data shows that the spreads have gone down dramatically. They do not collapse to zero as in the interbank market, but there are reasons to believe they have been reduced to a level compatible with an integrated market, as they are similar to the spreads within the US ${ }^{10}$. The remaining positive spreads correspond to credit and liquidity risks, which need not go away with market integration, although Danthine et al. argue that the market may end up eliminating even the liquidity risk associated with some issuers. In the public bond market, convergence has been as fast as in the interbank market, even though there remains a degree of dispersion in rates which has not disappeared with EMU.

\footnotetext{
9 Danthine et al. (2000), table 4.2., page 53.

10 See figure 4.3. in Danthine et al. (2000).
} 
With regard to the private bond market, this has been historically already fairly internationalized from the point of view of the firms present in the marketplace. The process of financial integration, and in particular the adoption of a single currency, has contributed very significantly to the further expansion of this market 11 and, most importantly for our purposes, has increased the degree of integration from the point of view of the location of investors. Already in 2000, Danthine et al. (2000) reported that an increasing proportion of euro issues by large firms in specific Member States were being placed in other EU markets. More systematically, recent research by Adam et al. (2002) has looked at the extent to which bond market funds in the EU have gradually moved to Europe-wide investment strategies. These authors conclude that the adoption of the euro led to a large increase in the asset share of internationally investing bond funds in eurozone countries, a process that has not taken place in the EU states that have not adopted the single currency.

Adam et al. consider similar measures with regard to stock exchanges. Consolidation in this market is proving difficult, but integration is taking place indirectly to the extent that investment institutions -and in many countries this means the leading universal banks- manage their investment funds, and UCITS in general, from an EU-wide perspective. Adam et al. (2002) analyze the changes in the asset composition of investment institutions across the EU. They conclude that, with the exception of France, Spain and Greece, the percentage of equity funds marketed in EU Member States that have an EU-wide investment strategy increased significantly between 1997 and $2001^{12}$.

Consider next the commercial banking market. We will focus on corporate loans for business and mortgages for residential customers. These are the markets for which comparable interest rates across the EU were collected by Adam et al. These rates show that price differences have not diminished over the years and in particular since EMU (see Table 1). The analysis by Adam et al. also shows little beta convergence over time ${ }^{13}$. This evidence is consistent with the fact that there has not been an upward trend in the presence of foreign credit institutions in individual EU retail banking markets ${ }^{14}$. The reduced penetration of foreign banks in domestic markets is not necessarily in contradiction with other trends which show that EU banks have become more internationalized over time. The data reported by the Bank for International Settlements (BIS) show that the share of foreign assets in total assets of EU-based banks has been growing continuously over the last ten years ${ }^{15}$. As argued before, this internationalization takes place through the lending and funding activities of domestic banks

For the purpose of examining the degree of integration of EU banking markets, these internationalization trends deserve closer examination. In particular, it is interesting to examine the relative position of non-EU and EU banks in this process, and whether the process of integration is taking place through branches or through subsidiaries. Tables $2 \mathrm{a}$ and

11 See, for example, European Commission (2001), page 142.

12 The integration process could also have taken place for the three countries above, if instead of using domestic funds, they had increased their share of foreign assets by acquiring directly foreign investment funds. This information is, however, unavailable. The results for these three countries could also be due to divergences in the way funds are classified.

13 See Adam et al. (2002) tables 5.1. to 5.3.

14 See Buch and Heinrich (2002) and ECB (1999a).

15 Between 1990 and 1995, the international assets (classified by nationality of ownership, table 8 of the BIS International Banking Statistics, see BIS Quarterly Review) of EU15 banks that report to the BIS grew by $10.6 \%$ per year, and the rate has been $12.7 \%$ between 1996 and 2001. Total assets for the same group of countries grew between 1997 and 2000 at an average rate of $6.9 \%$ (data from ECB 2002b, table 8). 
$2 \mathrm{~b}$ provide a summary of the relevant data for the period 1999-2001.

An examination of the trends, both in terms of number of units (Table 2a) and volume of assets (Table 2b), reveals two significant facts. The first is that there is a clear trend towards dominance of branches over subsidiaries (particularly in terms of units, less so in assets), although, as pointed out by Dermine (2002), the latter form remains important and that may be an indication of insufficient integration given the trends observed in the US. Rosengreeen (2002) uses the US benchmark and concludes that the persistence of subsidiaries may indeed reflect incomplete integration. He stresses, however, that the choice of incorporating in different jurisdictions is often related to tax and legal advantages offered by the host state. Such differences are, of course, more likely in the EU.

\begin{tabular}{|c|c|c|c|c|c|c|c|}
\hline \multirow[b]{2}{*}{ Branches } & \multicolumn{3}{|c|}{ intra-EEA } & \multicolumn{4}{|c|}{ Non-EEA } \\
\hline & 1997 & 2001 & $\%$ change & Branches & 1997 & 2001 & $\%$ change \\
\hline EU & 420 & 497 & 18 & $\mathrm{EU}$ & 297 & 216 & -27 \\
\hline $\begin{array}{l}\text { EU except UK and } \\
\text { Luxembourg }\end{array}$ & 259 & 356 & 37 & $\begin{array}{l}\text { EU except UK and } \\
\text { Luxembourg }\end{array}$ & 138 & 95 & -31 \\
\hline UK and Luxembourg & 161 & 141 & -12 & UK and Luxembourg & 159 & 121 & -24 \\
\hline Subsidiaries & $\begin{array}{l}\text { tra-EEA } \\
1997\end{array}$ & 2001 & $\%$ change & Subsidiaries & $\begin{array}{c}\text { EEA } \\
1997\end{array}$ & 2001 & $\%$ change \\
\hline EU & 301 & 328 & 9 & $\mathrm{EU}$ & 252 & 212 & -16 \\
\hline $\begin{array}{l}\text { EU except UK and } \\
\text { Luxembourg }\end{array}$ & 183 & 222 & 21 & $\begin{array}{l}\text { EU except UK and } \\
\text { Luxembourg }\end{array}$ & 128 & 100 & -22 \\
\hline UK and Luxembourg & 118 & 106 & -10 & UK and Luxembourg & 124 & 112 & -10 \\
\hline
\end{tabular}

* Sample of 10 countries in the EU (excluded countries are Austria, Denmark, Sweden, Greece and Ireland). Source: Own elaboration from ECB (2002b).

\begin{tabular}{|c|c|c|c|c|c|c|c|c|c|}
\hline \multirow[b]{2}{*}{ Branches } & \multicolumn{2}{|c|}{ Intra-EEA } & \multirow{2}{*}{$\begin{array}{c}\% \\
\text { change } \\
97-00\end{array}$} & \multirow{2}{*}{$\begin{array}{c}\% \\
\text { change } \\
97-01\end{array}$} & \multirow[b]{2}{*}{ Branches } & \multicolumn{2}{|c|}{ Non-EEA } & \multirow{2}{*}{$\begin{array}{c}\% \\
\text { change } \\
97-99\end{array}$} & \multirow{2}{*}{$\begin{array}{c}\% \\
\text { change } \\
97-01\end{array}$} \\
\hline & 1997 & 2001 & & & & 1997 & 2001 & & \\
\hline EU & 1261184 & 1941947 & 44 & 54 & EU & 1076806 & 1314853 & -6 & 22 \\
\hline $\begin{array}{l}\text { EU except } \\
\text { UK and Lux. }\end{array}$ & 316303 & 447523 & 37 & 41 & $\begin{array}{l}\text { EU except } \\
\text { UK and Lux. }\end{array}$ & 179618 & 98740 & -41 & -45 \\
\hline UK and Lux. & 944881 & 1494424 & 46 & 58 & UK and $L u x$ & 897188 & 1216113 & 1 & 36 \\
\hline & & ra-EEA & & & & Non- & EA & & \\
\hline Subsidiaries & 1997 & 2000 & 97-00 & & Subsidaries & 1997 & 1999 & $\begin{array}{l}\text { \% change } \\
\text { 97-99 }\end{array}$ & \\
\hline $\mathrm{EU}$ & 802898 & 1189829 & 48 & & EU & 485899 & 472122 & -3 & \\
\hline $\begin{array}{l}\text { EU except } \\
\text { UK and UK. }\end{array}$ & 412486 & 681378 & 65 & & $\begin{array}{l}\text { EU except } \\
\text { UK andLux. }\end{array}$ & 241810 & 208307 & -14 & \\
\hline
\end{tabular}

* Sample of 10 countries in the EU (excluded countries are Austria, Denmark, Sweden, Greece and Ireland). Million euros and percent change. 
Source: Own elaboration from ECB (2002b).

The second fact is that the trend towards a reduced presence of non-EEA banks continued strongly in the period 1997-2001, confirming the tendency already present in the data covering the early 1990s and reported in an ECB report in the late 1990s (op. cit. 1999).

An additional indicator of integration that is sometimes used is the geographical breakdown of mergers and acquisitions. This indicator suffers from the same drawbacks as the foreign market share and, in fact, if cross-border consolidation advanced, it would be also captured by the market share data. This information can, however, be particularly instructive when we compare EU trends with the US. Table 3 shows very clearly that the consolidation that took place during the second half of the nineties was characterized (as in earlier periods -see Gual and Neven (1993)) by its domestic nature. This is in sharp contrast to what has been observed in the US, where, as summarized by DeYoung (1999), most of the mergers and acquisitions have taken place between banks from different regions. In the US, moreover, antitrust activity may be restricting local consolidation, while in Europe very few domestic mergers have been blocked by regulators.

Table 3. Number of mergers and acquisitions in the EU

\begin{tabular}{|lrrrrrr|}
\hline \multicolumn{7}{|c|}{ Geographical breakdown } \\
\hline & 1995 & 1996 & 1997 & 1998 & 1999 & 2000 (up to June) \\
Total & 326 & 343 & 319 & 434 & 497 & 234 \\
Domestic & 275 & 293 & 270 & 383 & 414 & 172 \\
Intra-EU & 20 & 7 & 12 & 18 & 27 & 23 \\
Extra-EU & 31 & 43 & 37 & 33 & 56 & 39 \\
\hline
\end{tabular}

\begin{tabular}{|lcccccc|}
\hline \multicolumn{7}{|c|}{ Breakdown by size of domestic transactions } \\
\hline & $\mathbf{1 9 9 5}$ & $\mathbf{1 9 9 6}$ & $\mathbf{1 9 9 7}$ & $\mathbf{1 9 9 8}$ & $\mathbf{1 9 9 9}$ & $\mathbf{2 0 0 0}$ \\
$\%$ Large & $18 \%$ & $10 \%$ & $13 \%$ & $13 \%$ & $12 \%$ & $22 \%$ \\
$\%$ Small & $82 \%$ & $90 \%$ & $87 \%$ & $87 \%$ & $88 \%$ & $78 \%$ \\
\hline
\end{tabular}

Source: ECB (2000a).

Large: Mergers and acquisitions involving at least one firm with assets of one billion euros or more.

An alternative and complementary way to look at this is to analyze the evolution of the national concentration figures and the EU concentration ratio and compare this with the US outcome as reported by DeYoung (op. cit.). If mergers are taking place within borders, national concentration increases while EU-wide concentration need not increase. This is what has happened in Europe (see Charts 1 and 2), but not in the US, where local concentration indices have been comparatively constant, while the federal concentration ratio has increased markedly. 


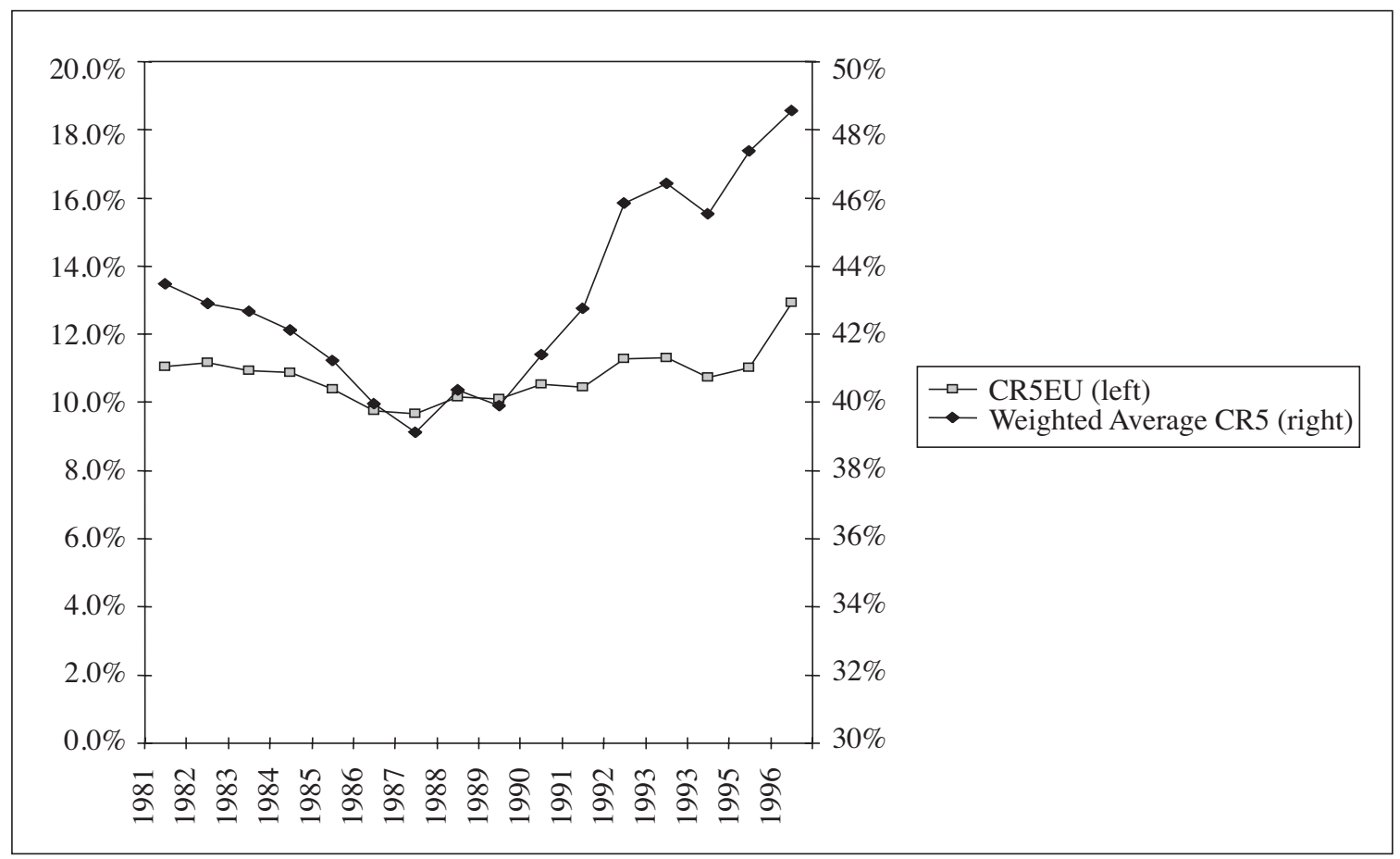

Chart 1. National concentration and EU-wide concentration, 1981-1996

Source: Updated from Gual (1999), based on data from The Banker and the OECD bank profitability dataset. Weights: Total assets of each national banking system.

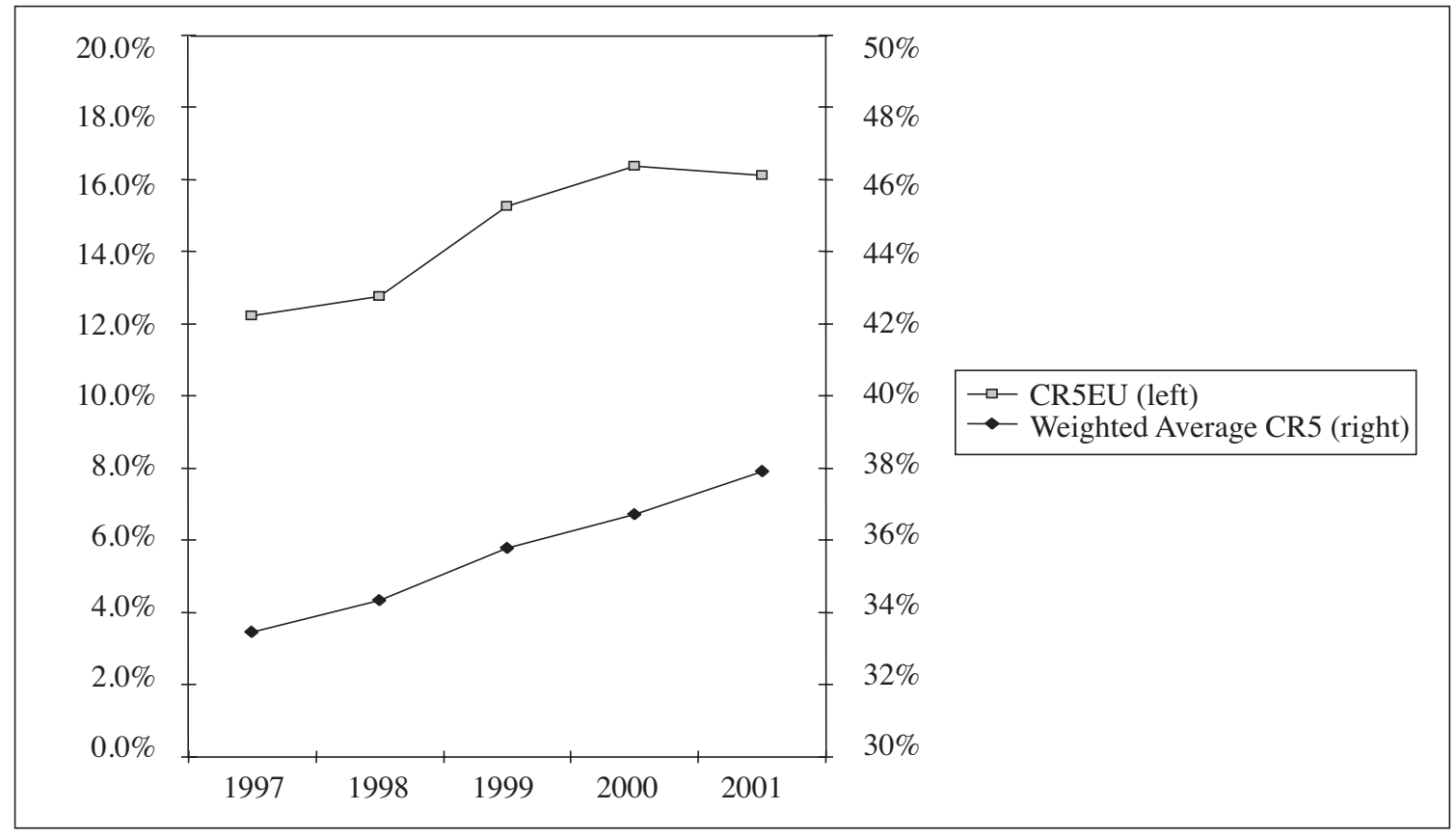

Chart 2. National concentration and EU-wide concentration, 1997-2001

Source: Weighted concentration data computed using data from ECB (2002b). EU-wide concentration computed using The Banker for the assets of the 5 largest EU banks. 
The divergence of trends in concentration in the US and the EU can be complemented with an analysis of concentration trends at the world level. Although it is difficult to collect the appropriate data, the information generated by the BIS project on consolidation provides a close enough approximation (see Table 4). These data seem to indicate that, indeed, the global process of internationalization and opening of banking markets is leading to a trend of increased concentration, whether we look at the top twenty or the top forty world banks ${ }^{16}$. If that is the case, it is clear that we should observe even faster trends of increased concentration in areas that, thanks to deregulation and market opening measures, are becoming single markets such as the EU and the US. As hypothesized elsewhere (Gual, 1999), such a process of consolidation would not accompany market enlargement if competition in the banking sector were based on conventional variables (with scale economies which may be significant, but of an exogenous nature, related to the technical aspects of the production process). Conversely, if we observe that market enlargement stimulates increased concentration, this may be due to the fact that the banking industry is increasingly characterized by competition in sunk fixed costs such as reputation, brand or the advantages of size related to the "too big to fail" perception by customers. If banking is characterized by these "endogenous sunk costs", then the aggregate EU figures in Charts 1 and 2 look all the more surprising. The slow increase in EU-wide concentration would thus confirm that political factors prevent cross-border consolidation.

Table 4. Worldwide concentracion

Assets of largest banks as a percent of total banking assets

\begin{tabular}{|lll|}
\hline & $\mathbf{1 9 9 0}$ & $\mathbf{1 9 9 7}$ \\
\hline Top 20 & $22 \%$ & $25 \%$ \\
Top 30 & $28 \%$ & $34 \%$ \\
Top 40 & $33 \%$ & $41 \%$ \\
Top 50 & $37 \%$ & $46 \%$ \\
\hline
\end{tabular}

Source: Own elaboration on the basis of Group of Ten (2001). The following 13 banking systems are included: USA, Canada, Australia, Japan, Switzerland, Germany, France, Belgium, Italy, Netherlands, Spain, Sweden and United Kingdom

Before finalizing the analysis of integration, it is worth recalling a very direct piece of evidence which has been highlighted repeatedly by the European Commission and which underlines the extent to which the single market project remains unfulfilled. The cost of cross-border retail payments compared to domestic transactions continues to be high and has not fallen significantly over the last ten years ${ }^{17}$. In 1993, the average charge for an EU crossborder credit transfer of 100 euros was 23.99 euros. Eight years later, the charge had risen to 24.09 euros, reflecting the high degree of segmentation of EU markets in this area ${ }^{18}$.

To conclude, the analysis of the integration process undertaken in this section points to the following key results. First, integration has taken place, albeit at different paces depending on the market segment. This is fully consistent with what we would expect given

16 The data refer to the banks of thirteen leading countries.

17 As reported by the EU Economic and Financial Committee. See European Commission (2002).

18 This is also pointed out by the ECB (2002c). 
the differences in the nature of competition in the existing lines of business of the industry. A second important result is that branches play an increasing role as a way to penetrate foreign markets, although -as discussed by Dermine - it may be a bit surprising that subsidiaries are still so important and this questions the effectiveness of EU integration measures. Finally, the data from 1997-2001 confirm the previous trend of a declining presence of non-EU banks, suggesting that the successful integration of EU banking markets may be generating a "trade diversion" effect ${ }^{19}$. That is, lower barriers within the EU lead to increased competitiveness of EU institutions relative to their non-EU rivals, despite the fact that non-EU banks benefit also from an enlarged local EU market.

\section{Conduct, structure and performance in EU banking markets}

The ultimate goal of the European Union integration policy in banking is not simply the creation of a large internal market. Rather, this policy goal is put forward as a key building block towards the final objective of achieving a more efficient EU financial service market which ultimately will contribute to higher economic growth and employment across the Union ${ }^{20}$.

In principle, a large single market will contribute to the development of deeper and more efficient financial services through well-known mechanisms. The larger market should in theory lead to a more competitive environment, with the development of stronger credit institutions, able to offer a wider and more complex array of financial products and services. Several reports commissioned by the EU have stressed the relationship between market size and efficiency and have attempted to estimate the magnitude of these effects ${ }^{21}$. More recently, the same type of arguments have been brought forward with regard to integration in financial services other than commercial banking 22 .

It is therefore necessary to assess the extent to which the increased integration of EU markets, which we have confirmed in the previous section, is having its predicted beneficial effects on the structure and performance of EU banking. We start by looking at the degree of competition and move on later to changes in market structure ${ }^{23}$.

Has integration in fact led to increased rivalry, as was predicted? Measuring the degree of rivalry is notoriously difficult, as has been stressed by a long tradition of research in the field of industrial organization. In recent years there has been a growing literature (the new empirical IO launched by Tim Bresnahan and others ${ }^{24}$ ) that has emphasized the need to estimate structural models of oligopoly competition. This literature has been sparsely applied to banking (see, for example, the paper by Neven and Röller (1999)), and certainly not with the goal of testing directly the extent to which the wider integration of EU banking markets has spurred wider rivalry.

19 The ECB has recently provided an analysis of the retreat of Japanese and US banks. See ECB (2002b).

20 On the relation between the efficiency of the financial service industry and economic growth see Gianetti et al. (2002), European Economy (2001) and the study by the Heinemann and Jopp (2002). See also DemirguçKunt and Levine (2001).

21 Economic Research Europe, (1996).

22 Heinemann and Jopp (2002) and London Economics (2002).

23 For reasons of space, we do not deal with issues of structure that affect the activities of banks in areas such as securities and insurance. Nor do we discuss in detail the presence of commercial banks in the UCITS market and in the disintermediation process (see, for example, Dermine (2002)).

24 See, for example, Bresnahan (1989) and more recently for differentiated product markets Nevo (2000). 
Nevertheless, the characteristics of competition in retail banking markets provide an easy-to-implement test of rivalry which is not a direct measurement of the degree of competition but very often a sufficiently close approximation. This is the so-called pass-thru test, which is based on the idea of assessing the degree of rivalry as captured by the extent to which changes in money market rates are passed through to retail rates.

This method makes sense if we can decouple the loan and deposit markets and assume that the money market rate provides an appropriate measure of the relevant opportunity costs for banks, both in terms of funding and in terms of allocating their investable funds. If that is the case, one can argue that the cost of funds in the money market is a good approximation to the short-run marginal costs which should form the basis of pricing. It is then easy to construct a model (known very often in the literature as the KleinMonti model) where retail rates (whether loan or deposit) depend -in the oligopolistic equilibrium- on money market rates. For a representative bank in the market, indexed by $j$, the first-order equilibrium condition which reflects profit maximization in the relevant market [1] looks as follows:

$$
\frac{r_{j t}-i_{t}}{r_{j t}}=\left(\frac{1}{e_{j t}}\right)
$$

where $i_{t}$ is the interbank rate, $r_{j t}$ is the retail rate (deposit or loans), and $e$ is the elasticity of the demand for loans (or supply of deposits) function faced by the bank. Equation [1] is of course a standard relation capturing the equilibrium between (short-run) marginal costs and perceived marginal revenue. With the introduction of additional restrictions, and aggregating over banks for each retail market, expression [1] can be transformed into [2] for the purposes of econometric analysis.

$$
r_{t}=\mu i_{t}
$$

where $\mu$ is a function of the elasticities faced by each firm, the degree of coordination between banks and the number of firms (for details, see Gual, 1993). In the simplest case, that of a monopoly, the relation between $\mu$ and the elasticity of demand $e$ is given by:

$$
\text { [3] } \mu=\frac{1}{1+1 / e}
$$

The parameter $\mu$ provides a good proxy of the degree of rivalry. Equation [2] is fairly intuitive: in more competitive markets the elasticity of demand is high ( $e$ is large in absolute value) and a change in the market interest rate will translate to a large degree into changes in the retail rate ( $\mu$ is close to one). In general, the elasticity, which determines the degree of market power, will depend on the existence of substitutes 25 as well as on the degree of coordination or collusion between existing market players.

(1) The basic equations are sketched here for the loan market, but a similar framework applies to deposits.

25 The response of retail rates may also depend on the level of interest rates if the demand or supply schedules are not isoelastic. 
The relevance of this simple relationship has to be qualified. There might be several sources of rigidities which need not reflect lack of competition. For example, if the interest rates being compared correspond to aggregates of financial services with different maturities. Or if menu costs are a significant source of price rigidity. More importantly, rates may be rigid due to the existence of asymmetric information. For example, when interbank rates go up, banks may not translate all the price increase into higher retail rates, since they know that this is likely to lead to a worsening of the loan portfolio 26 . Finally, rigidities may appear to the extent that banking competition is characterized by important switching costs (Klemperer, 1987). If banking clients face significant costs of switching banks, this may lead banks to compete on the basis of market share, anticipating the effect of current rate setting on the extent of market share and captive clients in the future. Such a dynamic competitive setup implies that banks take into account not only current interbank rates in the process of setting retail rates, but also their expected behaviour in the future. This may lead to more sluggish movements of rates which need not be the result of non-competitive behaviour. It will also imply that, in terms of the specification of [2], current retail rates will depend not only on current interbank rates, but also on future rates, as anticipated by the yield curve (for an application of this, see Gual, 1993).

Despite these shortcomings, pass-through analysis provides a much better indicator of the extent of competition than the use of simple markups (whether absolute or in percent terms), since the markups will be affected by both market power and cost differences. It is also better than the conventional intermediation margin (net interest income over assets) since this margin suffers from the same problem, as well as from differences in asset composition ${ }^{27}$.

During the 1990s several researchers looked at a variety of specifications of the pass-through model. Two of the most recent papers have looked at the EU retail markets precisely over the period that witnessed the process of liberalization and integration ${ }^{28}$.

Mojon (2000) provides an analysis of the magnitude of the pass-through effect and assesses whether it went down with the opening up of the markets in the 1990s. Corvoisier and Gropp (2001) go beyond this assessment and consider whether the trend of increased concentration that we have observed in many EU countries has countervailed the forces which led to increased competition as a result of the process of EU integration.

Mojon finds that interest rate rigidity is pervasive and, in common with previous studies on the subject, more important in the short run. Similarly, his study shows that differences across products and countries are substantial. The study also confirms the asymmetry of the pass-through. In the case of loans, rate increases are more easily passed on to consumers than rate decreases, while the opposite is true for deposit rates. This result, observed also in the US market, is consistent with a competition model where switching costs are important and where banks may set today's rates taking into account how this alters their future market share. For example, for the deposit market when interest rates go up, the gains from increased future market share are worth comparatively less (future profits from larger market share are more heavily discounted) and this will mean that banks may have an incentive to focus on profitability, by moderately raising their rates and increasing the markup. Conversely, if rates go down, the present value of future profits goes up and banks

26 See De Bondt (2002), page 9.

27 See also ECB (2000) "EU banks' margins and credit standards", December.

28 Another recent piece of work by Schüler and Heinemann (2002) looks at these issues using cointegration techniques. They find little integration for the consumer loans market and the savings deposit market. 
will be more interested in fully adjusting their rate downwards. Deposit rates will therefore be stickiest on their way up.

Table 5. Evidence on the interest rate pass-through

\begin{tabular}{|lcc|}
\hline & $\mathbf{1 9 7 9 - 8 8}$ & $\mathbf{1 9 8 8 - 9 8}$ \\
All & 0.50 & 0.45 \\
Credit & 0.59 & 0.59 \\
Breakdown by borrower & & \\
$\quad$ Short term credit to firms & 0.83 & 0.78 \\
$\quad$ Mortgages & 0.34 & 0.31 \\
Breakdown by country & & \\
$\quad$ Belgium & 0.31 & 0.56 \\
$\quad$ Germany & 0.74 & 0.66 \\
$\quad$ Spain & 0.17 & 0.28 \\
$\quad$ France & 0.79 & 0.75 \\
$\quad$ Italy & 0.90 & 0.62 \\
$\quad$ Netherlands & 0.76 & 0.75 \\
$\quad$ Deposits & 0,33 & 0.20 \\
Breakdown by country & & \\
$\quad$ Germany & 0.76 & 0.35 \\
$\quad$ Spain & 0.01 & 0.11 \\
$\quad$ Italy & 0.27 & 0.14 \\
$\quad$ Netherlands & 0.10 & 0.19 \\
\hline
\end{tabular}

Source: Mojon (2000) table 2b.

The author finds that deposit markets are stickier than credit markets on average. The most competitive markets appear to be those corresponding to short-term credit to firms. At the country level, Spain, Belgium and the Netherlands show the least flexibility (see Table 5). Most interesting for our purposes is the analysis of how the level of the pass-through changes within the sample period, which comprises 1979-1998. Mojon divides the sample in two periods, 1979-88 and 1988-98, and shows that stickiness goes down for several countries and markets, as predicted if competition has increased. However, this is certainly not the case for all instances.

Mojon goes on to analyze the determinants of the differences in the pass-through across countries and time. The results are revealing. He shows that a variable capturing the extent of deregulation through the adoption of the single banking market directives is an important contributor, in terms of explaining the magnitude of the pass-through as well as its asymmetry.

Corvoisier and Gropp (2001) do not look directly at the pass-through. Rather, starting from a Klein-Monti model of banking competition, they specify a regression model where the loan markup is a function of several structural variables and, in particular, 
measures of the degree of concentration in the market. They try to ascertain the extent to which the magnitude of the markup can be explained by measures of concentration. They find that for loans and demand deposits, the trend towards increased concentration has limited the reduction of the markup. This is not the case, however, in the markets for savings and time deposits.

One explanation of these results is that the markets for loans and demand deposits have poorer substitutes. With the development of UCITS and other investment vehicles, substitution away from deposits which are not needed for transactions is easier. By contrast, loan financing can only be substituted by direct financing and demand deposits are used for transactions, with very few alternatives available.

That the trend towards increased competition has been softened by the sharp increase in concentration seems to be confirmed by the fact that in Europe most mergers have not been used as an attempt to expand abroad (see section 3 above) but rather as a way to rationalize at home and possibly preserve market power.

Indeed, the trends in national concentration data confirm that over the period 199701 , concentration of local markets increased ${ }^{29}$. As shown in Chart 3, in the current phase the markets undergoing the biggest changes in concentration are the biggest and least concentrated markets.

\section{Chart 3.}

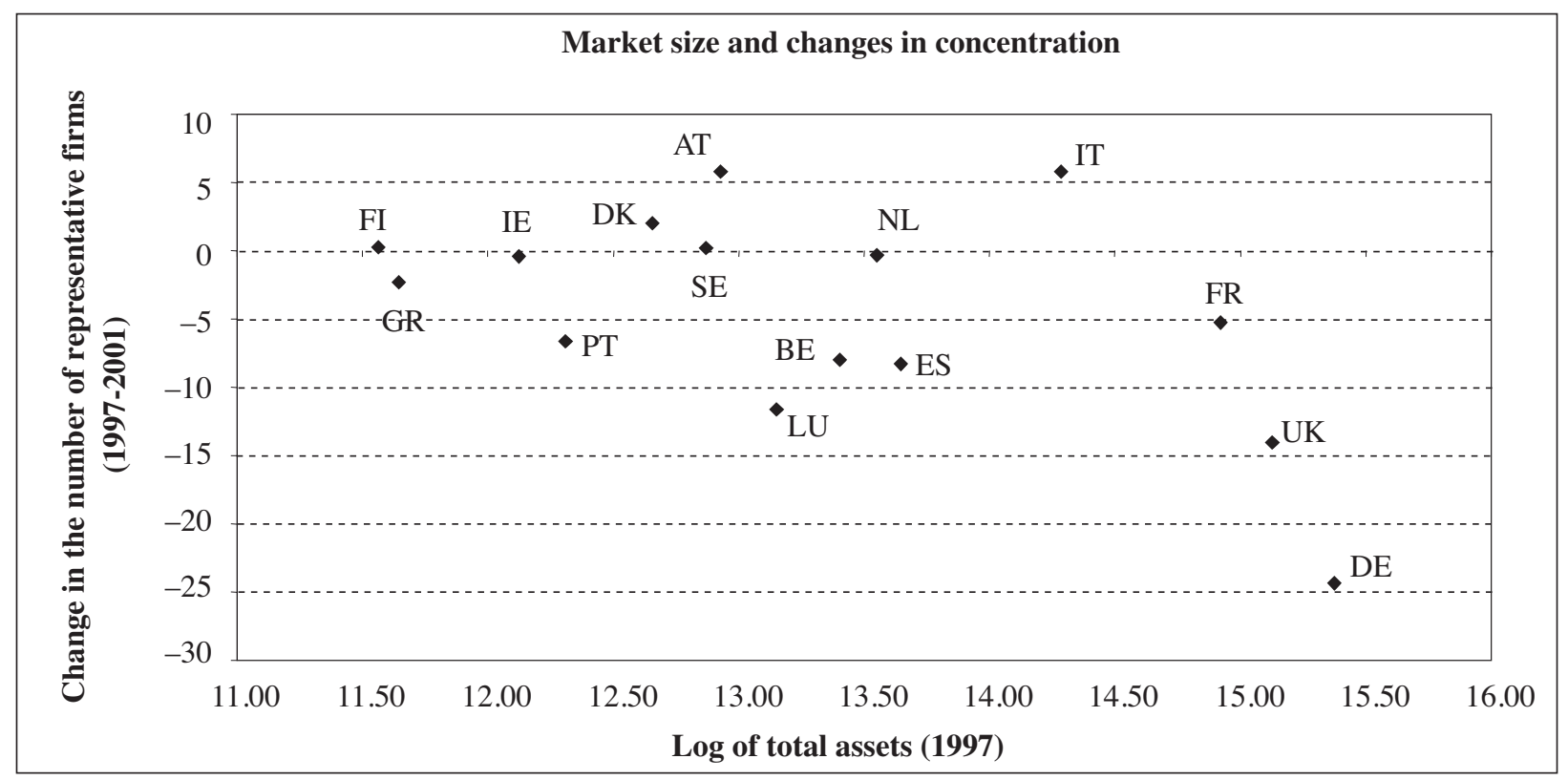

Source: Own elaboration from ECB (2002b). The number of representative firms is the inverse of the Herfindahl index. It is the number of symmetric firms which would lead to the same level of concentration as registered by the actual Herfindahl index.

29 For previous years see ECB (2000a) and Group of Ten (2001). However, the data are not fully coincident due to the use of different methodologies. 
We see, therefore, that the integration process has proceeded during the 1990s, with a limited effect on the degree of competition as captured by the changes in the markup, but with a substantial impact on the structure of the market, as measured both by changes in the concentration of the market through mergers and acquisitions, as well as by changes in the diversification of banks and their international exposures. Ultimately, however, it is important to assess whether the industry restructuring that has been triggered by European integration has led to increased welfare for EU citizens through the creation of a more efficient EU banking industry, and whether these efficiency gains have been transmitted to consumers in the form of lower markups, or to shareholders through profits.

Assessing efficiency is fairly complex, however. It can be attempted by estimating cost functions and production efficiency frontiers, or rather by examining simple balance sheet measures which are common in the industry -such as the cost-income ratio or ratios such as operating expenses (or staff costs) relative to non-bank deposit. The Group of Ten (2001) and Dermine (2002) provide recent surveys of the analytical work, and the descriptive data (covering the period 1990-1997) have been analyzed by the ECB ${ }^{30}$ reports and are available from the OECD bank profitability dataset. The literature review by Dermine and the Group of Ten, as well as the analysis of the data in the latter reports, confirm (Table 5 in Group of Ten (2001), comparing the US, the EU and Japan) that cost-income ratios tend to be somewhat smaller for large banks, but not necessarily for banks above 50 billion dollars in assets $^{31}$, and that within each bank category by size, there appears to be a large divergence in terms of efficiency, suggesting, as advanced a while ago by Humphrey (1987), that factors other than scale economies play a much more important role as a source of cost differences across banks. The report by the Group of Ten concludes that "M\&As do not significantly improve cost (...) There is evidence in favour of exploiting scale economies in retail banking up to a certain size (well below that of the most recent very large deals)" and that "Economies of scope are harder to pin down; there is no clear-cut evidence of their existence."

As for balance sheet data in the EU, the trend observed for these efficiency ratios is of a very moderate reduction. The data cover one major business cycle, and the key ratios typically worsen during 1993 and 1994, improving later on and sometimes achieving by the late 90s levels which are better than those of 1990. As reported by ECB (1999), it is clear that the industry has rationalized in terms of reducing the number of banks, branches or staff, say, per thousand inhabitants ${ }^{32}$. It is not that obvious, however, that this rationalization has translated into greater economic efficiency.

Another way to assess whether the process of integration has allowed European banks to reap the benefits of increased scale is to analyze the extent to which consolidation has increased the average size of banks, and the extent to which there has been a convergence in average bank size across the EU. The latter would reflect that banks in small countries are increasingly scaling their activities not on the basis of the domestic market, but rather of the EU market. This analysis can be done using the whole size distribution of credit institutions, or with a summary measure such as the average size. Instead of the size of the simple average bank, Chart 4 provides the size of the representative bank: a summary measure based on the

30 See ECB (1999a) and ECB (1999b).

31 Average for the period 1994-97. See table 5 in Group of Ten (2001). The category with the lowest costincome ratio comprises banks between 20 and 50 billion dollars in assets.

32 The data for operating expenses as a percentage of non-bank assets is available at ECB 1999b tables A.10 and A.11. For the cost-income ratio see ECB (1999a) table 9. 
Herfindahl concentration index (HHI) which takes into account not only how many banks there are but also their relative market shares ${ }^{33}$.

The evolution of these indicators over the period 1997-2001 shows that consolidation as well as organic growth have only partially removed the striking differences in bank size across the Union, and that the size of banks continues to be small and relatively unchanged in several markets such as Finland, Austria, Denmark and Italy (see Chart 4). These data support the idea that concentration processes based on national mergers have been a rather limited mechanism to enhance the efficiency of the industry.

Chart 4.

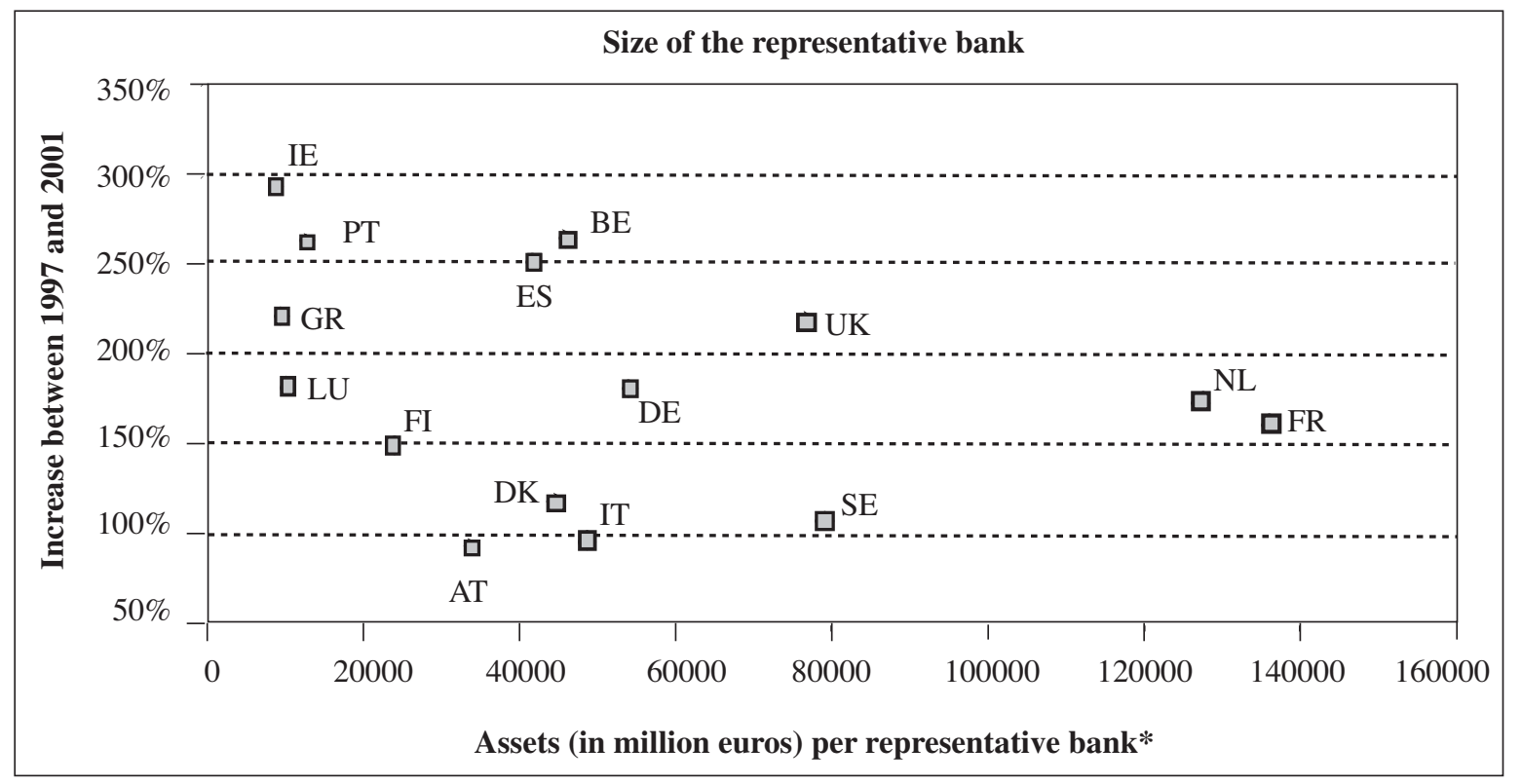

Source: Own elaboration from ECB (2002b).

Measurement problems become even more acute when we move on to assess profitability. A favoured industry standard is the analysis of ROE (Return on equity). Using the same sources as before, the data seem to indicate that over the 1990s average industry profitability for the EU has been fairly stable at around $10 \%$, with only a moderate cyclical decline during the 1993 recession ${ }^{34}$.

The use of an accounting measure such as ROE is, of course, debatable on the usual grounds (see Schmalensee (1989)). Moreover, in the particular case of EU banking, an industry that has gone through such a remarkable period of turbulence with deregulation, ROE has special shortcomings. Indeed, given the nature of the banking business, the appropriate benchmark for profitability should take into account not only the return on

33 Instead of Assets/Number of banks, we compute Assets/Number of Equivalent Banks (NE), where $\mathrm{NE}=1 / \mathrm{HHI}$. $\mathrm{NE}$ is the number of firms of equal market share which lead to an equivalent level of concentration (to the same HHI).

34 See ECB 1999a table 9. Data on return on equity for the period 1990-97. The Group of Ten report provides more recent harmonized data (based on the OECD Bank profitability dataset) which do not change this overall view. 
invested funds, but also its variability, since this has a direct impact on the solvency of a credit institution. Indeed, deregulation and integration allow banks to engage in a variety of new activities and markets. New revenue can accrue from these new areas and compensate for reduced margins in conventional banking. However, it could well be the case that this maintained profitability is achieved at the cost of increased variance.

Chart 5. The profitability of banking and financial intermediaries

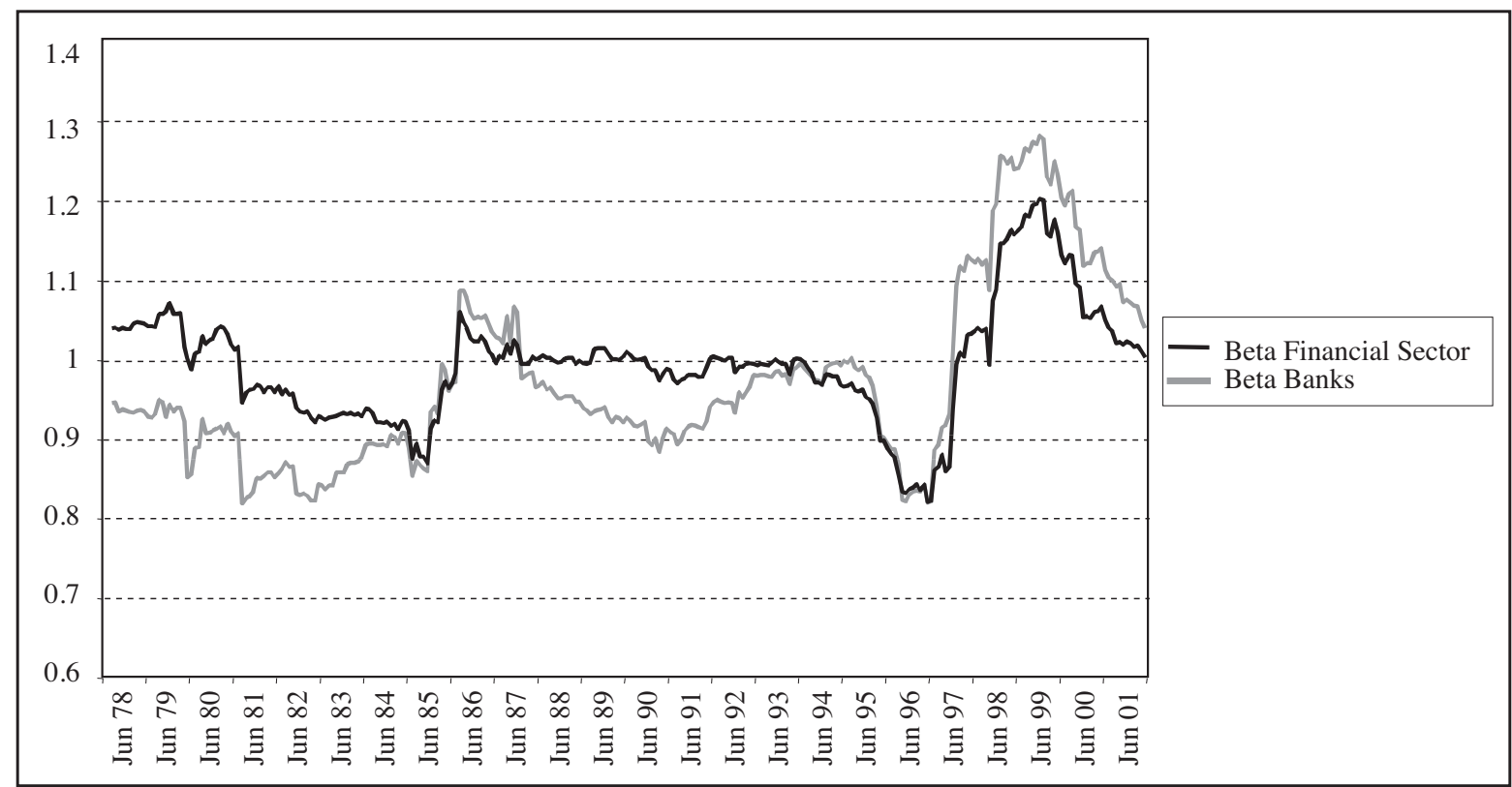

Source: Datastream.

Chart 6. The variability of returns in EU banking

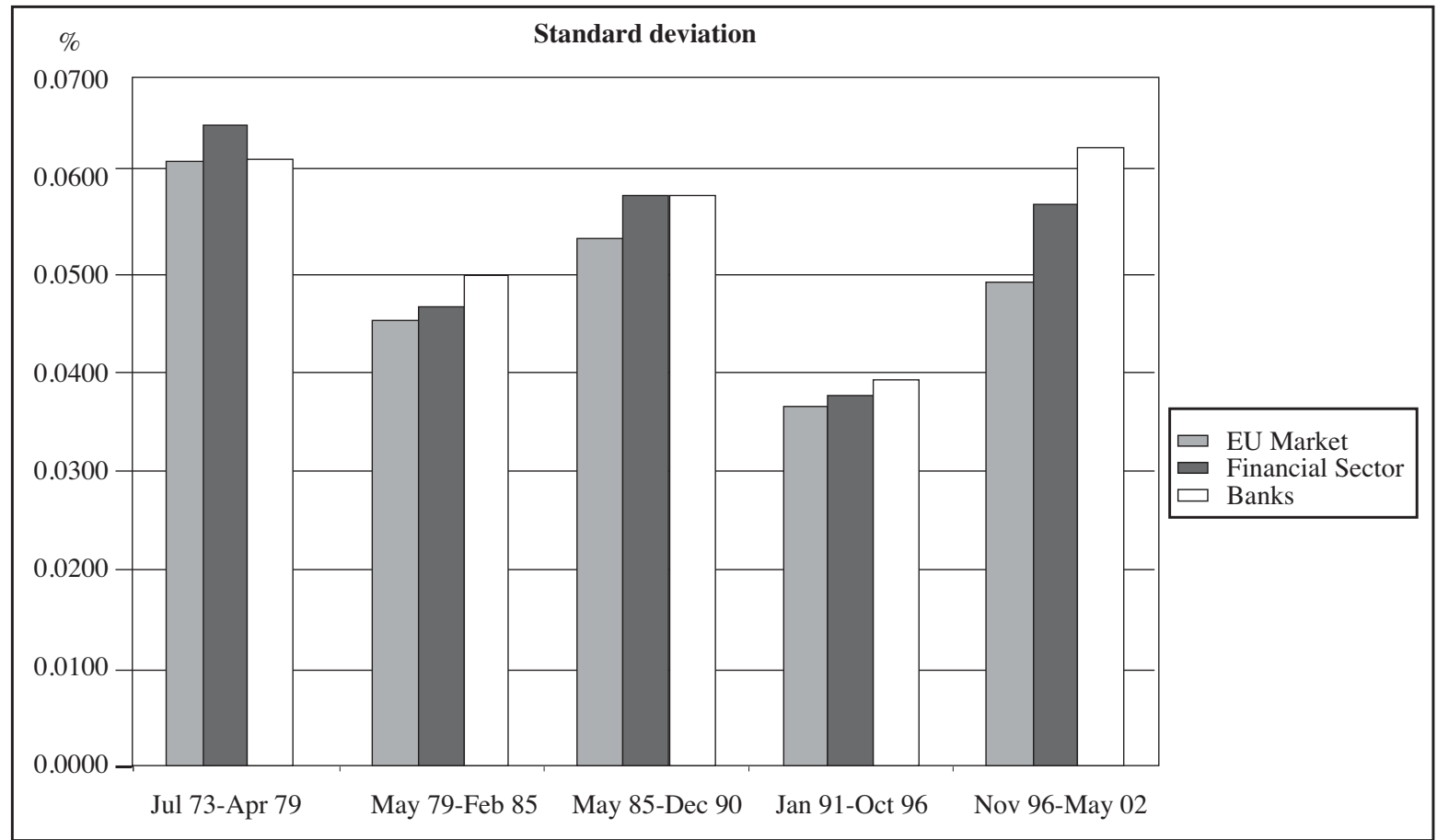

Note: Standard deviations of monthly returns for the corresponding periods.

Source: Own elaboration with data from Datastream. 
In fact, this is approximately what the evidence suggests for the case of the aggregate EU banking industry. As shown in Charts 5 and 6, it appears that the sectorspecific market risk associated with banking activities has been increasing over recent years, specially compared to the larger industry aggregate that includes the entire financial sector. In a similar vein, Chart 6 highlights the clear trend of the industry: a growing volatility of returns, higher than that of the financial sector or the market as a whole.

Overall, we conclude that integration has not led to a significant change in the degree of price competition in the industry (banks' rate-setting behaviour has not changed much). Rather, it has triggered dramatic changes in market structure, with consolidation in many national markets. It is not clear whether this process has improved the efficiency of the industry, but in any case it appears to have allowed industry participants to maintain their overall profitability. Nevertheless, the changing nature of banking, particularly in terms of revenue streams, with the increase in non-interest income as financial margins have deteriorated with the decline in interbank rates during the 1990s, implies that this maintenance of profitability has been coupled with a marked increase in the variability of banking returns.

\section{Concluding remarks}

Has EU policy been effective at integrating EU banking markets? This paper has attempted to answer this question while stressing that market integration is not an end in itself but rather that the final goal of the policy is to create a more efficient EU-wide banking market, while preserving such regulatory interventions as are firmly grounded in the market failures inherent in the banking industry.

As a consequence, any analysis of the effectiveness of the policy should be based on a broad assessment which takes into account not only the extent of integration of markets, but also how the market opening policies have impacted upon the performance of the industry from a private and social perspective.

The EU policy in this area has been based on the principle of mutual recognition. This method of integration implies that countries recognize each other's regulatory regime. It is a method of market opening for regulated industries which is more ambitious than the conventional trade approach based on the national treatment principle (market access with no discrimination of foreign companies) but less so than a full harmonization approach, where all firms compete subject to the same regulatory framework.

Since mutual recognition can trigger a competitive deregulation process, the general principle was complemented with a minimum harmonization level for prudential regulations. Similarly, in the area of regulation of the information received by bank clients, the EU policy has also introduced exemptions, allowing the national treatment principle (host country control).

This eclectic integration method implies that the competitive deregulation process has basically impacted upon economic regulations that do not pursue well-defined efficiency goals. The method has therefore been quite successful at triggering the opening of markets and the demise of arbitrary regulatory constraints on the activities of financial intermediaries. 
The degree of integration of banking markets has increased as a result of the EU single market policy and the adoption of the single currency. However, the integration is far from complete in retail markets for several reasons.

First, because in retail markets there are important natural and strategic barriers to entry which tend to keep markets segmented despite the introduction of market opening policies. Natural barriers such as language and distance imply that retail markets may continue to follow national borders (and even smaller geographical areas) for quite some time. Strategic barriers can also block market integration. Competition in retail banking is based on the deployment of assets such as branch network, brand and reputation (in part associated with bank size) and incumbent credit institutions may try to deploy these strategic assets in an attempt to gain competitive advantage in the process of market integration.

Indeed, an analysis of the conduct and the changes in the structure of the industry in recent years shows that the industry has reacted to the double pressure of integration and the single currency with an increase in the concentration of domestic markets, as a way to rationalize costs and protect market power. Such a competitive reaction is consistent with the observed evolution of competition, which has increased only mildly and for a few market segments (a limited effect in terms of the flexibility of the markup), and with the stability of overall profitability.

The strategic reaction of incumbent banks through domestic consolidation implies that some of the goals of integration have not been achieved. Markups could have declined faster, pricing could be more flexible, and banks could have increased their size by way of cross-border mergers, where the benefits of scale are clearer, according to most empirical studies. It appears that, in some instances, political constraints have prevented the crossborder consolidation process. Similarly, in certain Member States political interference may have allowed the achievement of very large concentration levels despite their potentially negative effect on bank clients.

Despite its limited impact on the degree of competition, the new competitive environment prompted by deregulation and integration has forced banks to diversify, increase their lines of business and engage in financial innovation, with an overall increase in business risk and the volatility of profits. These trends may have prudential implications, although it seems that those can be tackled with the harmonized solvency standards. It is uncertain, however, whether this process of increased volatility has impacted upon banks operating at the EU level, where potential solvency problems may have an impact extending beyond the country that controls the bank in terms of prudential regulations (see Dermine 2002).

A second key reason why the integration process is not complete in retail banking has to do with the exceptions introduced in the integration process by allowing host country control in certain areas. These exceptions, which allow the imposition of local regulations when the general interest is at risk, should, in principle, ensure that domestic preferences are properly taken into account in the integration process. It is clear, however, that the preservation of the general good can be used as a legal instrument with protectionist objectives. The preeminence of local rules should be accepted only when it can be shown that no comparable home country regulation serves the same objective, and that the local rule cannot be used discriminatorily against foreign providers. Competition policy, a policy which can be forcefully deployed by EU authorities to preserve the general EU interest, should be used in these instances, if local regulators use the general interest argument as a protectionist device. 
The process of assessing whether these exceptions to the mutual recognition principle are appropriate or not is bound, however, to be fairly complex and politically controversial. Integration will be limited, on the other hand, because other important differences across countries regarding company law, contract law and fiscal matters will remain, and will facilitate the segmentation of markets. Given the high degree of integration already achieved, additional steps may require a higher degree of harmonization. As recently argued by Don Cruickshank ${ }^{35}$, chairman of the London Stock Exchange, if the Member States of the EU really wish to achieve a fully integrated financial market, the EU institutions need a stronger political mandate. After all, more integration will imply that EU-wide objectives take precedence over local preferences, and this is not possible without further political integration. In the meantime, the current system, complemented by the use of the wide powers of the European Commission in competition policy to guarantee no discrimination, is probably the most that can be achieved.

\section{References}

Adam, K., T. Japelli, A. Menichini, M. Padula and M. Pagano (2002) “Analyse, compare and apply alternative indicators and monitoring methodologies to measure the evolution of capital market integration in the EU". Report to the European Commission. January, University of Salerno.

Belaisch A., L. Kodres, J. Levy and A. Ubide (2001) "Euro-Area Banking at the Crossroads", IMF Working Paper, 01/28.

Bresnahan, Tim (1989) "Empirical Studies of Industries with Market Power", in Schmalensee and Willig (eds.), Handbook of Industrial Organization, volume II, 1011:1058, Amsterdam: North Holland.

Buch, C.M. and R.P. Heinrich (2002) "Financial Integration in Europe and Banking Sector Performance" in Heineman, F. and M. Jopp (2002) "The Benefits of a Working European Retail Market for Financial Services".

Corvoisier, S. and Gropp, R. (2001) "Bank Concentration and Retail Interest Rates", ECB Working Paper \# 72, July.

Danthine, J.P., Giavazzi, F. and E.L. von Thadden (2000) "European Financial Markets after EMU: A First Assessment", CEPR Discussion Paper 2413, April.

Danthine, J.P., Giavazzi, F., Vives, X. and E.L. von Thadden (1999) "The Future of European Banking", Monitoring European Integration No. 9, London: CEPR.

De Bandt, O. and E. Davis (1999) "A Cross-Country Comparison of Market Structures in European Banking", ECB Working Paper \# 7, September.

De Bondt, Gabe (2002) "Retail bank interest pass-through: new evidence at the euro area level", ECB Working Paper \# 136, April.

Demirgüç-Kunt and Levine (ed.) (2001) Financial Structure and Economic Growth, Boston: MIT Press.

Dermine, Jean (2002) "European Banking: past, present and future". Paper presented at the 2nd ECB Central Banking Conference on "The transformation of the European financial system”, Frankfurt am Main, 24-25 October.

DeYoung, Robert (1999) "Mergers and the Changing Landscape of Commercial Banking (part I)", Chicago Fed Letter, \# 145, September.

ECB (1999a) "Possible Effects of EMU on the EU Banking Systems in the Medium to Long Term”, February, Frankfurt am Main.

35 “A single market requires political union” Financial Times, 22 January 2003. 
ECB (1999b) "The effects of technology on the EU banking systems", July, Frankfurt am Main.

ECB (2002a) "Report on Financial Structures", Frankfurt am Main.

ECB (2002b) "Structural Analysis of the EU Banking Sector. Year 2001", November, Frankfurt am Main.

ECB (2002c) "Payment and Securities Settlement systems in the EU. Addendum incorporating 2000 figures, blue book". July, Frankfurt am Main.

ECB, (2000a) "ECB Mergers and Acquisitions Involving the EU Banking Industry - Facts and Implications", December, Frankfurt am Main.

ECB, (2000b) "EU Banks' Margins and Credit Standards", December, Frankfurt am Main.

Economic Research Europe (1996), "A Study of the Effectiveness and Impact of Internal Market Integration on the Banking and Credit Sector", Report for the European Commission, The Single Market Review, Brussels.

European Commission (2001) "Financial Market Integration in the EU", European Economy \#73, 125:174.

European Commission (2002) "Report by the Economic and Financial Committee (EFC) on EU financial integration", Economic Papers \# 171, DGECFIN, May.

Gianetti et al. (2002) "Financial Market Integration, Corporate Financing and Economic Growth", Economic Papers \#179. Final Report (22 November).

Group of Ten (2001) "Report on Consolidation in the Financial Sector", January, available at www.bis.org.

Gual, J. (1993) "La competencia en el mercado español de depósitos bancarios", Moneda y Crédito 196, 143:179.

Gual, J. (1999) "Deregulation, Integration and Market Structure in European Banking", Journal of the Japanese and International Economies, 13 (4), December.

Gual, J. and D. Neven, (1993) "Deregulation of the European Banking Industry", European Economy/Social Europe, \#3, 153:183.

Heineman, F. and M. Jopp (2002) "The Benefits of a Working European Retail Market for Financial Services", Report to the European Financial Services Round Table, available at: http://www.zew.de/en/forschung/erfstudyresults.html

Humphrey, D. (1987) "Cost dispersion and the measurement of economies in banking", Federal Reserve Bank of Richmond Economics Review, May/June.

Klemperer, Paul (1987) "Markets with consumers switching costs", Quarterly Journal of Economics, 102 (2), 375-394.

London Economics (2002) "Quantification of the macroeconomic impact of integration of EU financial markets", A report to the European Commission. November, Brussels.

Mojon, B. (2000) "Financial structure and the interest rate channel of ECB monetary policy", ECB Working Paper \#40, November.

Neven, Damien J. and Röller, Lars-Hendrik (1999) "An Aggregate Structural Model of Competition in the European Banking Industry", International Journal of Industrial Organization, 17(7), 1059:1074.

Nevo, Aviv (2000) “A Practitioner's Guide to Estimation of Random Coefficients Logit Models of Demand", Journal of Economics and Management Strategy, volume 9, \#4, Winter, 513:548.

Rosengreen, Eric (2002) "Comment on European Banking: Past, Present and Future", 2nd ECB Central Banking Conference on "The transformation of the European financial system", Frankfurt am Main, 24-25 October.

Schmalensee, R. (1989) "Inter-industry studies of structure and performance", in Schmalensee, R. and R.D. Willig (eds.), Handbook of Industrial Organization, volume II, 952:1009, Amsterdam: North Holland.

Schüler, M. and Heinemann, F. (2002) "How integrated are European Retail Financial Markets? A Cointegration Analysis", in Heinemann and Jopp (2002). 
Sun, J.-M. and J. Pelkmans, (1995) "Regulatory Competition in the Single Market", Journal of Common Market Studies, volume 33, \#1, March.

Van Empel, M. and A. Mörner (2000) "Financial Services and Regional Integration", in Claessens, S. and M. Jansen (eds.), The Internationalization of Financial Services. Issues and Lessons for Developing Countries, London: Kluwer.

White, L. (1996) "Competition versus Harmonization: An Overview of International Regulation of Financial Services", in C. Barfield (ed.), International Financial Markets: Harmonization versus Competition, Washington: American Enterprise Institute. 